\title{
SEATING POSITION AND STUDENT LEARNING APPROACH RELATIONSHIP IN A BUSINESS SUBJECT ON A LIFE SCIENCE DEGREE
}

\author{
N. Lajara, A. Pérez-de-Castro, M. Leiva-Brondo \\ Universitat Politècnica de València (SPAIN)
}

\begin{abstract}
In higher education, where students are able to choose the seating position from where they are attending their lectures, the seating choice becomes an interesting, and curious, matter of research. Up to date, most of the published works have related the position in class to the academic performance, measured mainly through grades. The interest of this contribution relies in the use of the student approach to learning of each student -classified as Deep approach or Surface Approach, measured using the Biggs' R-SPQ-2F questionnaire- as possible explanatory variable for their most frequent seating position. A correlation analysis allows to state if there is any relationship between these elements. A sample of students from first year of the Degree in Biotechnology at Universitat Politècnica de València was gathered to assess this relationship. Their most frequent position in class was determined by a series of pictures that were taken throughout the course and the student approach to learning was assessed at the beginning of the term with the R-SPQ-2F questionnaire. Results can provide instructors with some guidelines to address their attention and intention in class activities to the groups that they target.
\end{abstract}

Keywords: R-SPQ-2F; deep and surface approach; assessment; teaching methodology.

\section{INTRODUCTION}

Student performance in classrooms can be affected by several factors like study habits, family and peer support or student approach to learning for example [1], [2]. Seating position is one factor that has influence in academic performance and can easily be manipulated by the teacher in the classroom [1]. In general, a close position to the teacher is positively correlated with fewer absences and better performance [3], which has been contrasted in different studies [4]-[6]. The election of the position influence the performance, as "better students" chose to sit closer to the teacher [1], but when students were "forced" to sit closer, it also improved their marks [7]. Random assignation also improved performance on students closer to the teacher in some studies [8], although others showed no influence [9], [10]. Other factors like computer use also influenced student performance linked to seating position [1], as well as factors like personality [11] or motivation [12], which are also correlated with seating position and academic performance.

Student approach to learning also influence academic performance and student learning [2], [13]-[15]. Student approach to learning can be divided in two main categories: deep and surface approach [16][18]. This classification student's approaches to learning (SAL) theory was initially developed by Marton and Säljö [19], [20]. Entwistle [21], [22] and Biggs [23] developed further this theory. The knowledge of student approach to learning is a useful tool to improve teacher performance [24]. Students with a surface approach are characterized by no intrinsic motivations and their main aim is only to meet the subject requirements [24]-[27]. This approach is normally correlated with a worst academic performance [2]. Students that have a deep approach in a subject normally have an intrinsic motivation, their main aim is to learn [24]-[26], [28] and they have a better academic performance [2], [13]-[15].

The student normally varies his/her approach to learning depending on different factors. Three steps model has been proposed by Biggs [29]: Presage, process and product. And the list of factors can affect student approach [23], [30], [31]. Personal factors like personality, gender, age, social context, previous knowledge or skills have been reported as influencers of student approach to learning [2], [23], [30], [32], [33]. Gender factor influence changes depending on the study as some indicate that females show a deeper approach and others that males [15], [32], [34]-[36]. Also, age of the student show an increment of deep approach [33], [36]-[38] possibly because they have more intrinsic motivation [39]. 
Other factors that can affect student approach to learning are classified as contextual factors, like the teaching methodology or the assessment system, the year of the subject and the subjects that are also chosen by the student, the type of studies or the discipline, [23], [30], [40], [41]. As approach is not a fixed characteristic of the student, they can change their approach between different subjects and years [40], [42]-[45]. For example, a lower deep approach was observed in third-year students compared with first year students [23] and similar results were observed in other studies [45]-[47]. However, it is not a general trend as other studies showed no change [46], [48]-[50], and others a decline in surface approach [51], [52]. Teacher performance is one of the contextual factors than can affect student election [37], [41], [53]-[58]. Also student perception of contextual factors can affect student approach to learning [23], [30], [40], like workload, teaching system, clarity of goals or the assessment system [30], [41], [54], [58]. Course requirements can change student approach to learning, for example [59].

The assessment of student approach to learning can be determined by different instruments like Study Attitudes and Methods Revised Short Form (SAMS Short Form) [60], Inventory of Learning ProcessRevised (ILP-R) [61], Revised Approaches to Studying Inventory (RASI) [62] modified in Approaches and Study Skills Inventory for Students (ASSIST) [63], [64], Approaches to Learning and Studying Inventory (ALSI) [22], Learning and Study Inventory Strategies (LASSI) [65], or Inventory of Learning Styles (ILS) [66] are some of the instruments developed. In the present study the Revised 2 factor version (R-SPQ-2F) [16] has been used. This questionnaire has been translated to different languages [25], [67]-[71] and determines the student approach to learning in two main scales (deep and surface) and two subscales (motivation and strategy) The questionnaire is developed to assess the student approach to learning in a particular subject or situation [16], [26], [72].

In this study the student approach to learning of the students was assessed in Biotechnology Business Economics in year 2020-2021 of the Biotechnology degree, with the R.SPQ-2F questionnaire at the beginning of the subject. Also, the seating position of students was recorded in several moments of the term and related to their student approach to learning.

\section{METHODOLOGY}

Biotechnology Business Economics subject has six European Credit Transfer System (ECTS), three of theory sessions (30 hours) and three of practical sessions (classroom and computer sessions). The number of students enrolled was of 103. The subject is organized with one group with Spanish as language used for instruction and the other with English. The learning platform based in Sakai called PoliformaT was used to deliver all the materials and to perform assessment activities.

The study was carried out with a sample of 33 students, all of them enrolled in the English group. This constrain is due to the COVID restrictions applied in Spanish universities during the academic year 2020-2021 that affect to the available seating positions in each classroom. The application of such measures has meant for the Spanish group that the students needed to split the groups between two classrooms, being one of them the one where the teacher is lecturing and the other, that acts as a "mirror" class, connecting via Teams to the lecture or from home. This extraordinary situation would have introduced a bias in the study that would have been difficult to overcome. Nevertheless, the English group, due to its more reduced size, had the possibility of attending altogether in the same classroom.

The reference for the seating position was the most frequent area in which the student has been seating during the course. In order to determine this, a series of pictures were randomly taken in several moments of the term. In addition to this, a survey was conducted in the last month of lectures asking the students to confirm their most frequent area of seating during the term. To that purpose, the classroom was divided into nine areas (Figure 1), coding such areas according to laterality and frontrear position. 




Figure 1: Sketch of the coded areas dividing the classroom.

The R-SPQ-2F questionnaire developed by Biggs [16] was submitted to the students at the beginning of the term on-line through University learning platform Sakai-based PoliformaT. Statgraphics Centurion XVII (Statpoint Technologies, Inc.) was used to analyse the results calculating correlations between factors and Cronbach's alpha values.

The academic performance was measured through the grade the students obtained in an objective exam carried out at mid-term. The test had two parts: multiple choice quiz and problems, each part accounted for the $50 \%$ of the grade of the exam.

The relationship between the variables was assessed both through a correlation analysis and an analysis of variance, ANOVA. The Spearman correlation coefficient was chosen attending to the reduced sample and the ordinal nature of the seating variables (row, column). An analysis of variance was applied to verify the differences found and a post-hoc analysis was used to determine the groups where those significant dissimilarities have been found. These analyses have been performed using IBM ${ }^{\circ}$ SPSS $®$ Statistics version 25.

\section{RESULTS}

The sample was composed of 33 students, 14 men and 19 women. The rate of response was of $89 \%$. They had an average grade of $6.69 \pm 0.24$ (out of 10) and, in average, show a deeper approach to learning in relation to the course of Business Economics with no differences regarding to gender (Table 1). The most frequent position for the students was row 2 and column 3.

Table 1: Characterization of the sample.

\begin{tabular}{|c|c|c|c|c|c|c|c|c|}
\hline & $\begin{array}{l}\text { No. answers } \\
\text { (\% enrolled) }\end{array}$ & Grade & & $D A$ & $S A$ & & $D A-S A$ & $\begin{array}{c}\text { Null hypothesis } \\
\text { DA-SA }\end{array}$ \\
\hline Total & $33(0.89)$ & $6.69 \pm 0.24$ & & $3.20 \pm 0.10$ & $1.93 \pm 0.08$ & & $1.27 \pm 0.15$ & *** \\
\hline \multicolumn{9}{|l|}{ Gender } \\
\hline Female & $19(0.83)$ & $6.58 \pm 0.33$ & a & $3.19 \pm 0.15$ & a $1.79 \pm 0.12$ & a & $1.40 \pm 0.23$ & $* * *$ \\
\hline Male & $14(1.00)$ & $6.85 \pm 0.38$ & a & $3.20 \pm 0.13$ & a $2.11 \pm 0.09$ & a & $1.09 \pm 0.16$ & *** \\
\hline
\end{tabular}

${ }^{1}$ Different letters in the same column indicate significant differences ( $P$-value<0.05) between groups according to Tukey's test.

$2 * * *: P<0.0001,{ }^{* *} 0.001<P<0.0001,{ }^{*} 0.01<P<0.001, N S>0.01$ 
The correlation analysis showed a significant relation between the row (front, middle, rear) and the grade obtained but there was apparently no relationship between seating position and the learning approach shown by students (Table 2).

Table 2: Correlation between seating position measured through row and column and grade, deep approach (DA) and surface approach (SA) obtained by the student using Spearman's Rho.

\begin{tabular}{lllcc} 
& Column & Grade & DA & SA \\
\hline Row & $-0.051^{\mathrm{NS}}$ & $-0.346^{*}$ & $0.081^{\mathrm{NS}}$ & $0.006^{\mathrm{NS}}$ \\
Column & & $-0.144^{\mathrm{NS}}$ & $-0.121^{\mathrm{NS}}$ & $-0.010^{\mathrm{NS}}$ \\
Grade & & & $0.252^{\mathrm{NS}}$ & $0.122^{\mathrm{NS}}$ \\
DA & & & & \\
SA & & & & \\
\hline${ }^{*} P<0.05, \mathrm{NS}>0.05$ & & &
\end{tabular}

An analysis of variance was applied in order to detect significant differences among the different categories of the factor (row; column) in dependent variables (grade, DA, SA). In this analysis, therefore, the null hypothesis establishes that there were no significant differences between the mean values of the variables grade, DA and SA between the three zones defined in the class for each position variable (row; column). In the event of non-compliance with this hypothesis, that is, the choice of seat was related to the learning approach and/or the grade obtained, it will be necessary to determine in which groups such differences occurred.

Table 3. Values (average and standard error) of the grade and R-SPQ-2F questionnaire scales deep approach (DA) and surface approach (SA) related the position of the student in the classroom.

\begin{tabular}{|c|c|c|c|c|c|c|c|c|c|}
\hline & No. answers & Grade & & $D A$ & & $S A$ & & $D A-S A$ & \\
\hline \multicolumn{10}{|c|}{ Row } \\
\hline 1 & 9 & $6.99 \pm 0.40$ & $a b$ & $3.03 \pm 0.16$ & a & $1.88 \pm 0.14$ & $a$ & $1.14 \pm 0.15$ & a \\
\hline 2 & 16 & $7.12 \pm 0.35$ & $b$ & $3.34 \pm 0.16$ & $a$ & $1.99 \pm 0.12$ & $a$ & $1.34 \pm 0.25$ & a \\
\hline 3 & 8 & $5.51 \pm 0.38$ & $a$ & $3.10 \pm 0.18$ & a & $1.84 \pm 0.17$ & $\mathrm{a}$ & $1.26 \pm 0.34$ & a \\
\hline \multicolumn{10}{|c|}{ Column } \\
\hline 1 & 10 & $6.36 \pm 0.40$ & a & $3.01 \pm 0.21$ & a & $1.93 \pm 0.15$ & $a$ & $1.08 \pm 0.33$ & a \\
\hline 2 & 11 & $6.89 \pm 0.49$ & a & $3.55 \pm 0.14$ & a & $1.95 \pm 0.18$ & $a$ & $1.60 \pm 0.28$ & a \\
\hline 3 & 12 & $6.79 \pm 0.39$ & $a$ & $3.03 \pm 0.13$ & a & $1.91 \pm 0.09$ & $a$ & $1.13 \pm 0.15$ & a \\
\hline
\end{tabular}

${ }^{1}$ Different letters in the same column indicate significant differences ( $P$-value<0.05) between groups according to Tukey's test.

There were not significant differences between the different levels shown by the factor "column" related to grade or student approach to learning. Significant differences regarding grades were found for the variable "row" while no differences were observed regarding the student approach to learning (Table 3). Post -hoc analysis using Tamhane were applied to study the nature of these differences (Table 4). Some studies have showed that seating position is not related to academic performance, but room type can affect [10], but other studies show a negative impact in student's grade related with further from the instructor is the student located [1].

Table 4: Post-hoc comparisons using Tamhane between Row and Grade.

\begin{tabular}{cccccccc} 
Dependent variable & (I) Row & J) Row & (I-J) & Std. Dev. Sig. & Lower limit Upper limit \\
\hline Grade & 1.00 & 2.00 & -0.128 & 0.536 & 0.993 & -1.522 & 1.266 \\
& & 3.00 & $1.487^{*}$ & 0.552 & 0.049 & 0.004 & 2.971 \\
& \multirow{2}{*}{2.00} & 1.00 & 0.1278 & 0.5312 & 0.993 & -1.266 & 1.522 \\
& & 3.00 & $1.615^{*}$ & 0.511 & 0.016 & 0.269 & 2.961 \\
\hline
\end{tabular}

*. Differences in means are significant at 0.05 . 
Based on the results obtained we noted that there are significant differences between the mean grades obtained by students that usually seat in the front and middle area of the classroom compared to those that usually seat at the rear part, being lower these latter. The election of the seating position by the student is due to several factors, one of them is the personality, for example students that seat closer to the instructor tend to be more assertive [11], but also the room type affects this choice [10]. Gender is also a factor that can affect seating position as women sit in front of the classroom more often than men [6]. Random assignation of seating position also affected academic performance of the students [8].

\section{CONCLUSIONS}

Seating position is one factor that has influence in academic performance and can easily be manipulated by the teacher in the classroom [1]. In general, a close position to the teacher is positively correlated with fewer absences and better performance [3], which has been contrasted in different studies [4]-[6]. Our results showed a difference regarding academic performance with higher marks in the middle row of the classroom compared with the other rows. The position has not shown significant regarding the learning approach. However, the conditions in the classroom were affected by the Covid pandemic situation and results should be repeated in different conditions. In addition to that, size of the sample and other factors can affect the results, so more repetitions are needed to assess this result [11].

\section{ACKNOWLEDGEMENTS}

The publication of this work has been funded by a project of Educational Improvement and Innovation awarded by the Vice Dean for Studies, Quality and Accreditation of the Universitat Politècnica de València (Spain).

\section{REFERENCES}

[1] P. Will, W. F. Bischof, and A. Kingstone, "The impact of classroom seating location and computer use on student academic performance," PLoS One, vol. 15, no. 8, p. e0236131, Aug. 2020, doi: 10.1371/journal.pone.0236131.

[2] Y. Salamonson et al., "Learning approaches as predictors of academic performance in first year health and science students," Nurse Educ. Today, vol. 33, no. 7, pp. 729-733, Jul. 2013, doi: 10.1016/j.nedt.2013.01.013.

[3] V. A. Tagliacollo, G. L. Volpato, and J. Pereira, Alfredo, "Association of student position in classroom and school performance," Educ. ..., vol. 1, no. 6, pp. 198-201, 2010, [Online]. Available: http://interesjournal.org/ER/pdf/2010/July/Tagliacollo et al.pdf.

[4] F. D. Becker, R. Sommer, J. Bee, and B. Oxley, "College Classroom Ecology," Sociometry, vol. 36, no. 4, p. 514, Dec. 1973 , doi: $10.2307 / 2786247$.

[5] K. Zomorodian et al., "The effect of seating preferences of the medical students on educational achievement," Med. Educ. Online, vol. 17, no. 1, p. 10448, Jan. 2012, doi: 10.3402/meo.v17i0.10448.

[6] C. I. Brooks and J. L. Rebeta, "College Classroom Ecology," Environ. Behav., vol. 23, no. 3, pp. 305-313, May 1991, doi: 10.1177/0013916591233003.

[7] F. Blume, R. Göllner, K. Moeller, T. Dresler, A.-C. Ehlis, and C. Gawrilow, "Do students learn better when seated close to the teacher? A virtual classroom study considering individual levels of inattention and hyperactivity-impulsivity," Learn. Instr., vol. 61, no. November 2018, pp. 138-147, Jun. 2019, doi: 10.1016/j.learninstruc.2018.10.004.

[8] K. K. Perkins and C. E. Wieman, "The Surprising Impact of Seat Location on Student Performance," Phys. Teach., vol. 43, no. 1, pp. 30-33, Jan. 2005, doi: 10.1119/1.1845987. 
[9] S. Kalinowski and M. Toper, "The Effect of Seat Location on Exam Grades and Student Perceptions in an Introductory Biology Class," J. Coll. Sci. ..., vol. 36, no. 4, pp. 54-57, 2007, [Online].

Available: http://search.ebscohost.com/login.aspx?direct=true\&profile=ehost\&scope=site\&authtype=crawler \& jrnl=0047231X\&AN=23550203\&h=TywLPU3YaDXRsIRa3xYPHKIm74f7fxYaY13fh+fayeLkY3Rh vdoSmCQ7mDUJA9mujisAbR8SP6Ktb0OcqDzYfA==\&crl=c.

[10] M. Meeks, T. Knotts, K. James, F. Williams, J. Vassar, and A. Wren, "The Impact of Seating Location and Seating Type on Student Performance," Educ. Sci., vol. 3, no. 4, pp. 375-386, Oct. 2013, doi: 10.3390/educsci3040375.

[11] P. F. Totusek and A. Q. Staton-Spicer, "Classroom Seating Preference as a Function of Student Personality," J. Exp. Educ., vol. 50, no. 3, pp. 159-163, Mar. 1982, doi: 10.1080/00220973.1982.11011818.

[12] J. M. Burda and C. I. Brooks, "College Classroom Seating Position and Changes in Achievement Motivation over a Semester," Psychol. Rep., vol. 78, no. 1, pp. 331-336, Feb. 1996, doi: 10.2466/pro.1996.78.1.331.

[13] W. May, E.-K. Chung, D. Elliott, and D. Fisher, "The relationship between medical students' learning approaches and performance on a summative high-stakes clinical performance examination," Med. Teach., vol. 34, no. 4, pp. e236-e241, Apr. 2012, doi: 10.3109/0142159X.2012.652995.

[14] C. K. F. Mok, B. Dodd, and T. L. Whitehill, "Speech-language pathology students' approaches to learning in a problem-based learning curriculum," Int. J. Speech. Lang. Pathol., vol. 11, no. 6, pp. 472-481, Jan. 2009, doi: 10.3109/17549500903003052.

[15] N. Dong, M. Bai, H. Zhang, and J. Zhang, "Approaches to learning IFRS by Chinese accounting students," J. Account. Educ., vol. 48, pp. 1-11, Sep. 2019, doi: 10.1016/j.jaccedu.2019.04.002.

[16] J. Biggs, D. Kember, and D. Y. P. Leung, "The revised two-factor Study Process Questionnaire: R-SPQ-2F," Br. J. Educ. Psychol., vol. 71, no. 1, pp. 133-149, Mar. 2001, doi: 10.1348/000709901158433.

[17] N. Entwistle and D. Entwistle, "Preparing for examinations: The interplay of memorising and understanding, and the development of knowledge objects," High. Educ. Res. Dev., vol. 22, no. 1, pp. 19-41, 2003, doi: 10.1080/0729436032000056562.

[18] D. Kember, J. Biggs, and D. Y. P. Leung, "Examining the multidimensionality of approaches to learning through the development of a revised version of the Learning Process Questionnaire," $\mathrm{Br}$. J. Educ. Psychol., vol. 74, no. 2, pp. 261-279, Jun. 2004, doi: 10.1348/000709904773839879.

[19] F. Marton and R. Säljö, "On qualitative differences in learning: I-Outcome and process," Br. J. Educ. Psychol., vol. 46, no. 1, pp. 4-11, Feb. 1976, doi: 10.1111/j.2044-8279.1976.tb02980.x.

[20] F. Marton and R. Säljö, "On qualitative differences in learning-Il outcome as a function of the learners's conception of the task," Br. J. Educ. Psychol., vol. 46, no. 2, pp. 115-127, Jun. 1976, doi: 10.1111/j.2044-8279.1976.tb02304.x.

[21] N. ENTWISTLE and S. WATERSTON, "APPROACHES TO STUDYING AND LEVELS OF PROCESSING IN UNIVERSITY STUDENTS," Br. J. Educ. Psychol., vol. 58, no. 3, pp. 258-265, Nov. 1988, doi: 10.1111/j.2044-8279.1988.tb00901.x.

[22] N. Entwistle, V. McCune, and J. Hounsell, "Approaches to Studying and Perceptions of University Teaching-Learning Environments: Concepts, Measures and Preliminary Findings," Edinburgh, 2002. doi: 10.13140/RG.2.2.33594.80329.

[23] J. Biggs, Student Approaches to Learning and Studying. Research Monograph. Melbourne: Australian Council Educational Research (ACER), 1987.

[24] J. Biggs and C. Tang, Teaching for quality learning at university. (4th Edn.), 4th editio. Berkshire: Open University Press McGraw-Hill, 2011.

[25] Y. F. Zakariya, K. Bjørkestøl, H. K. Nilsen, S. Goodchild, and M. Lorås, "University students' learning approaches: An adaptation of the revised two-factor study process questionnaire to Norwegian," Stud. Educ. Eval., vol. 64, no. May 2019, p. 100816, Mar. 2020, doi:

10.1016/j.stueduc.2019.100816. 
[26] A. Stes, S. De Maeyer, and P. Van Petegem, "Examining the Cross-Cultural Sensitivity of the Revised Two-Factor Study Process Questionnaire (R-SPQ-2F) and Validation of a Dutch Version," PLoS One, vol. 8, no. 1, p. e54099, Jan. 2013, doi: 10.1371/journal.pone.0054099.

[27] G. Vanthournout, L. Coertjens, D. Gijbels, V. Donche, and P. Van Petegem, "Assessing students' development in learning approaches according to initial learning profiles: A person-oriented perspective," Stud. Educ. Eval., vol. 39, no. 1, pp. 33-40, Mar. 2013, doi: 10.1016/j.stueduc.2012.08.002.

[28] B. Vaughan, "A Rasch analysis of the Revised Study Process Questionnaire in an Australian osteopathy student cohort," Stud. Educ. Eval., vol. 56, no. December, pp. 144-153, 2018, doi: 10.1016/j.stueduc.2017.12.003.

[29] J. B. Biggs, "From Theory to Practice: A Cognitive Systems Approach," High. Educ. Res. Dev., vol. 12, no. 1, pp. 73-85, 1993, doi: 10.1080/0729436930120107.

[30] M. Baeten, E. Kyndt, K. Struyven, and F. Dochy, "Using student-centred learning environments to stimulate deep approaches to learning: Factors encouraging or discouraging their effectiveness," Educ. Res. Rev., vol. 5, no. 3, pp. 243-260, Jan. 2010, doi: 10.1016/j.edurev.2010.06.001.

[31] L. K. Fryer, "Building Bridges: Seeking Structure and Direction for Higher Education Motivated Learning Strategy Models," Educ. Psychol. Rev., vol. 29, no. 2, pp. 325-344, Jun. 2017, doi: 10.1007/s10648-017-9405-7.

[32] Q. Xie and L. fang Zhang, "Demographic Factors, Personality, and Ability as Predictors of Learning Approaches," Asia-Pacific Educ. Res., vol. 24, no. 4, pp. 569-577, 2015, doi: 10.1007/s40299-014-0202-5.

[33] D. Gijbels, G. Van de Watering, F. Dochy, and P. Van den Bossche, "The relationship between students' approaches to learning and the assessment of learning outcomes," Eur. J. Psychol. Educ., vol. 20, no. 4, pp. 327-341, Dec. 2005, doi: 10.1007/BF03173560.

[34] R. Z. Elias, "Students' Approaches to Study in Introductory Accounting Courses," J. Educ. Bus., vol. 80, no. 4, pp. 194-199, Mar. 2005, doi: 10.3200/JOEB.80.4.194-199.

[35] P. Everaert, E. Opdecam, and S. Maussen, "The relationship between motivation, learning approaches, academic performance and time spent," Account. Educ., vol. 26, no. 1, pp. 78-107, Jan. 2017, doi: 10.1080/09639284.2016.1274911.

[36] J. T. E. Richardson, "Approaches to studying across the adult life span: Evidence from distance education," Learn. Individ. Differ., vol. 26, pp. 74-80, Aug. 2013, doi: 10.1016/j.lindif.2013.04.012.

[37] L. Gow and D. Kember, "Does higher education promote independent learning?," High. Educ., vol. 19, no. 3, pp. 307-322, 1990, doi: 10.1007/BF00133895.

[38] J. T. E. Richardson and E. King, "Adult Students in Higher Education: Burden or Boon?," J. Higher Educ., vol. 69, no. 1, p. 65, Jan. 1998, doi: 10.2307/2649182.

[39] G. Harper and D. Kember, "Approaches to Study of Distance Education Students," Br. J. Educ. Technol., vol. 17, no. 3, pp. 212-222, Oct. 1986, doi: 10.1111/j.1467-8535.1986.tb00510.x.

[40] P. Zeegers, "Approaches to learning in science: A longitudinal study," Br. J. Educ. Psychol., vol. 71, no. 1, pp. 115-132, Mar. 2001, doi: 10.1348/000709901158424.

[41] M. G. Eley, "Differential adoption of study approaches within individual students," High. Educ., vol. 23, no. 3, pp. 231-254, Apr. 1992, doi: 10.1007/BF00145015.

[42] G. Piumatti, M. Abbiati, M. W. Gerbase, and A. Baroffio, "Patterns of Change in Approaches to Learning and Their Impact on Academic Performance Among Medical Students: Longitudinal Analysis," Teach. Learn. Med., vol. 0, no. 0, pp. 1-11, Oct. 2020, doi: 10.1080/10401334.2020.1814295.

[43] H. Asikainen and D. Gijbels, "Do Students Develop Towards More Deep Approaches to Learning During Studies? A Systematic Review on the Development of Students' Deep and Surface Approaches to Learning in Higher Education," Educ. Psychol. Rev., vol. 29, no. 2, pp. 205-234, Jun. 2017, doi: 10.1007/s10648-017-9406-6. 
[44] J. Nieminen, S. Lindblom-Ylänne, and K. Lonka, "The Development of Study Orientations and Study Success in Students of Pharmacy," Instr. Sci., vol. 32, no. 5, pp. 387-417, Sep. 2004, doi: 10.1023/B:TRUC.0000044642.35553.e5.

[45] M. Leiva-Brondo et al., "Study Approaches of Life Science Students Using the Revised TwoFactor Study Process Questionnaire (R-SPQ-2F)," Educ. Sci., vol. 10, no. 7, p. 173, Jun. 2020, doi: 10.3390/educsci10070173.

[46] P. Lietz and B. Matthews, "The Effects of College Students' Personal Values on Changes in Learning Approaches," Res. High. Educ., vol. 51, no. 1, pp. 65-87, Feb. 2010, doi: 10.1007/s11162-009-9147-6.

[47] J. Wilding and B. Andrews, "Life goals, approaches to study and performance in an undergraduate cohort," Br. J. Educ. Psychol., vol. 76, no. 1, pp. 171-182, Mar. 2006, doi: 10.1348/000709904X24726.

[48] P. Zeegers, "Student learning in higher education: a path analysis of academic achievement in science," High. Educ. Res. Dev., vol. 23, no. 1, pp. 35-56, Feb. 2004, doi: 10.1080/0729436032000168487.

[49] L. Rodriguez and F. Cano, "The learning approaches and epistemological beliefs of university students: a cross-sectional and longitudinal study," Stud. High. Educ., vol. 32, no. 5, pp. 647-667, Oct. 2007, doi: 10.1080/03075070701573807.

[50] J. A. Ballantine, A. Duff, and P. McCourt Larres, "Accounting and business students' approaches to learning: A longitudinal study," J. Account. Educ., vol. 26, no. 4, pp. 188-201, Dec. 2008, doi: 10.1016/j.jaccedu.2009.03.001.

[51] M. Hall, A. Ramsay, and J. Raven, "Changing the learning environment to promote deep learning approaches in first-year accounting students," Account. Educ., vol. 13, no. 4, pp. 489-505, Dec. 2004, doi: 10.1080/0963928042000306837.

[52] C. Gordon and R. Debus, "Developing deep learning approaches and personal teaching efficacy within a preservice teacher education context," Br. J. Educ. Psychol., vol. 72, no. 4, pp. 483-511, 2002, doi: 10.1348/00070990260377488.

[53] J. S. Jeong, D. González-gómez, M. C. Conde-núñez, and A. Gallego-picó, "Examination of students ' engagement with R-SPQ- $2 \mathrm{~F}$ of learning approach in flipped sustainable science course," J. Balt. Sci. Educ., vol. 18, no. 6, pp. 880-891, 2019, [Online]. Available: http://www.scientiasocialis.lt/jbse/?q=node/811.

[54] N. J. Entwistle and H. Tait, "Approaches to learning, evalutions of teaching, and perferences for contrasting academic environments," High. Eduation, vol. 19, no. 2, pp. 291-299, 1990.

[55] S. F. Leung, E. Mok, and D. Wong, "The impact of assessment methods on the learning of nursing students," Nurse Educ. Today, vol. 28, no. 6, pp. 711-719, Aug. 2008, doi: 10.1016/j.nedt.2007.11.004.

[56] J. Biggs, "What the Student Does: teaching for enhanced learning," High. Educ. Res. Dev., vol. 18, no. 1, pp. 57-75, Apr. 1999, doi: 10.1080/0729436990180105.

[57] D. Gijbels, L. Coertjens, G. Vanthournout, E. Struyf, and P. Van Petegem, "Changing students' approaches to learning: a two-year study within a university teacher training course," Educ. Stud., vol. 35, no. 5, pp. 503-513, Dec. 2009, doi: 10.1080/03055690902879184.

[58] K. Trigwell, M. Prosser, and F. Waterhouse, "Relations between teachers' approaches to teaching and students' approaches to learning," High. Educ., vol. 37, no. 1, pp. 57-70, 1999, doi: 10.1023/A:1003548313194.

[59] S. E. Volet, P. D. Renshaw, and K. Tietzel, "A short-term longitudinal investigation of cross-cultural differences in study approaches using Biggs' SPQ questionnaire," Br. J. Educ. Psychol., vol. 64, no. 2, pp. 301-318, Jun. 1994, doi: 10.1111/j.2044-8279.1994.tb01104.x.

[60] W. B. Michael, J. J. Michael, and W. S. Zimmerman, Study Attitudes and Methods Survey (SAMS). San Diego, CA: Educational and Industrial Testing Service, 1985. 
[61] R. R. Schmeck, F. Ribich, and N. Ramanaiah, "Development of a Self-Report Inventory for Assessing Individual Differences in Learning Processes," Appl. Psychol. Meas., vol. 1, no. 3, pp. 413-431, Jun. 1977, doi: 10.1177/014662167700100310.

[62] N. J. Entwistle and H. Tait, The revised approaches to studying inventory. Edinburgh, Scotland: Centre for Research on Learning and Instruction, 1995.

[63] H. Tait, N. J. Entwistle, and V. McCune, "ASSIST: a reconceptualisation of the Approaches to Studying Inventory," in Improving students as learners, C. Rust, Ed. Oxford: Oxford Brookes University, The Oxford Centre for Staff and Learning Development., 1998, pp. 262-271.

[64] N. Entwistle and T. Hilary, "Approaches and Study Skills Inventory for Students (ASSIST) (incorporating the Revised Approaches to Studying Inventory - RASI)," 2013, [Online]. Available: https://www.researchgate.net/publication/260291730_Approaches_and_Study_Skills_Inventory_f or_Students_ASSIST_incorporating_the_Revised_Approaches_to_Studying_Inventory_-_RASI.

[65] C. E. Weinstein, Learning and Study Strategies Inventory. Clearwater, FL: H \& H Publishing, 1987.

[66] J. D. Vermunt, Inventory of Learning Styles in Higher Education: Scoring key. Tilburg, The Netherlands: Tilburg University, Department of Educational Psychology, 1994.

[67] M. López-Aguado and L. Gutiérrez-Provecho, "Checking the underlying structure of R-SPQ-2F using covariance structure analysis," Cult. y Educ., vol. 30, no. 1, pp. 105-141, 2018, doi: 10.1080/11356405.2017.1416787.

[68] A. Socha and E. A. Sigler, "Exploring and 'reconciling' the factor structure for the Revised Twofactor Study Process Questionnaire," Learn. Individ. Differ., vol. 31, pp. 43-50, Apr. 2014, doi: 10.1016/j.lindif.2013.12.010.

[69] D. KEMBER and L. GOW, "Cultural specificty of approaches to study," Br. J. Educ. Psychol., vol. 60, no. 3, pp. 356-363, Nov. 1990, doi: 10.1111/j.2044-8279.1990.tb00952.x.

[70] F. Justicia, M. C. Pichardo, F. Cano, A. B. G. Berbén, and J. De la Fuente, "The Revised TwoFactor Study Process Questionnaire (R-SPQ-2F): Exploratory and confirmatory factor analyses at item level," Eur. J. Psychol. Educ., vol. 23, no. 3, pp. 355-372, Sep. 2008, doi: 10.1007/BF03173004.

[71] L. K. Fryer, P. Ginns, R. A. Walker, and K. Nakao, "The adaptation and validation of the CEQ and the R-SPQ-2F to the Japanese tertiary environment," Br. J. Educ. Psychol., vol. 82, no. 4, pp. 549-563, Dec. 2012, doi: 10.1111/j.2044-8279.2011.02045.x.

[72] D. Kember, "MISCONCEPTIONS ABOUT THE LEARNING APPROACHES, MOTIVATION AND STUDY PRACTICES OF ASIAN STUDENTS," in The RoutledgeFalmer Reader in Higher Education, vol. 40, no. 1, Abingdon, UK: Taylor \& Francis, 2000, pp. 37-55. 